\title{
Correction to: Does pulmonary subspecialty referral from primary care affect the adherence to vaccination recommendations in COPD patients?
}

Solmaz Ehteshami-Afshar ${ }^{1 *}$, Kristina Crothers², Benjamin Rodwin ${ }^{1,3}$, Brett Bade $^{1,3}$, Cynthia Brandt ${ }^{4,5}$ and Kathleen M. Akgün 1,3,4*

\section{Correction to: Respir Res (2021) 22:50}

https://doi.org/10.1186/s12931-021-01639-6

Following publication of the original article [1], we were notified that the last author, Kathleen M. Akgün, should have also been marked as a corresponding author.

The original article has been corrected.

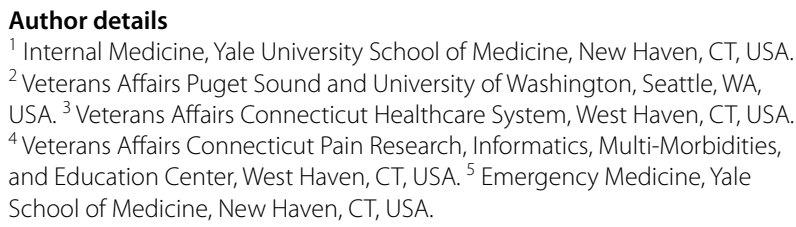

${ }^{1}$ Internal Medicine, Yale University School of Medicine, New Haven, CT, USA. ${ }^{2}$ Veterans Affairs Puget Sound and University of Washington, Seattle, WA, USA. ${ }^{3}$ Veterans Affairs Connecticut Healthcare System, West Haven, CT, USA. ${ }^{4}$ Veterans Affairs Connecticut Pain Research, Informatics, Multi-Morbidities, and Education Center, West Haven, CT, USA. ${ }^{5}$ Emergency Medicine, Yale School of Medicine, New Haven, CT, USA.

Published online: 15 March 2021

\section{Reference}

1. Ehteshami-Afshar S, Crothers K, Rodwin B, Bade B, Brandt C. Akgün KM (2021) Does pulmonary subspecialty referral from primary care affect the adherence to vaccination recommendations in COPD patients? Respir Res. 2021;22:50. https://doi.org/10.1186/s12931-021-01639-6.

\section{Publisher's Note}

Springer Nature remains neutral with regard to jurisdictional claims in published maps and institutional affiliations.
The original article can be found online at https://doi.org/10.1186/s1293 1-021-01639-6.

${ }^{*}$ Correspondence: solmaz.ehteshamiafshar@yale.edu;

kathleen.akgun@yale.edu

${ }^{1}$ Internal Medicine, Yale University School of Medicine, New Haven, CT,

USA

Full list of author information is available at the end of the article

(c) The Author(s) 2021. Open Access This article is licensed under a Creative Commons Attribution 4.0 International License, which permits use, sharing, adaptation, distribution and reproduction in any medium or format, as long as you give appropriate credit to the original author(s) and the source, provide a link to the Creative Commons licence, and indicate if changes were made. The images or other third party material in this article are included in the article's Creative Commons licence, unless indicated otherwise in a credit line to the material. If material is not included in the article's Creative Commons licence and your intended use is not permitted by statutory regulation or exceeds the permitted use, you will need to obtain permission directly from the copyright holder. To view a copy of this licence, visit http://creativecommons.org/licenses/by/4.0/. The Creative Commons Public Domain Dedication waiver (http://creativeco mmons.org/publicdomain/zero/1.0/) applies to the data made available in this article, unless otherwise stated in a credit line to the data. 